\title{
ApoE Lipidation as a Therapeutic Target in Alzheimer's Disease
}

\author{
Maria Fe Lanfranco, Christi Anne Ng $\mathbb{D}$ and G. William Rebeck * $\mathbb{D}$ \\ Department of Neuroscience, Georgetown University Medical Center, 3970 Reservoir Road NW, \\ Washington, DC 20057, USA; m11358@georgetown.edu (M.F.L.); cn472@georgetown.edu (C.A.N.) \\ * Correspondence: gwr2@georgetown.edu; Tel.: +1-202-687-1534
}

Received: 6 August 2020; Accepted: 30 August 2020; Published: 1 September 2020

\begin{abstract}
Apolipoprotein E (APOE) is the major cholesterol carrier in the brain, affecting various normal cellular processes including neuronal growth, repair and remodeling of membranes, synaptogenesis, clearance and degradation of amyloid $\beta(\mathrm{A} \beta)$ and neuroinflammation. In humans, the APOE gene has three common allelic variants, termed E2, E3, and E4. APOE4 is considered the strongest genetic risk factor for Alzheimer's disease (AD), whereas APOE2 is neuroprotective. To perform its normal functions, apoE must be secreted and properly lipidated, a process influenced by the structural differences associated with apoE isoforms. Here we highlight the importance of lipidated apoE as well as the APOE-lipidation targeted therapeutic approaches that have the potential to correct or prevent neurodegeneration. Many of these approaches have been validated using diverse cellular and animal models. Overall, there is great potential to improve the lipidated state of apoE with the goal of ameliorating APOE-associated central nervous system impairments.
\end{abstract}

Keywords: apolipoprotein E; cholesterol; lipid homeostasis; neurodegeneration

\section{Scope of This Review}

In this review, we will first consider the role of apolipoprotein $\mathrm{E}$ (apoE) in lipid homeostasis in the central nervous system (CNS). We will then summarize data on the effects of $A P O E$ genotype on apoE function and lipid trafficking in normal functions and in pathogenesis. Finally, we will speculate on ways to increase lipidation of apoE with the goal to decrease apoE-associated CNS impairments.

\section{Introduction}

ApoE, a $34 \mathrm{kDa}$ protein composed of 299 amino acids, is a member of the superfamily of amphiphilic exchangeable apolipoproteins. It is expressed in hepatocytes, monocytes/macrophages, adipocytes, astrocytes, and kidney cells. In humans, the APOE gene has three common alleles, $\varepsilon 2$, $\varepsilon 3$, and $\varepsilon 4$ with frequencies in the US population of: $\varepsilon 2,7 \% ; \varepsilon 3,79 \%$; and $\varepsilon 4,14 \%$, but this distribution varies widely with ethnicity and geography [1-4].

$A P O E 4$ is considered the strongest genetic risk factor for the development of Alzheimer's disease (AD). APOE4 also affects other neurological disorders, including poor clinical outcomes after traumatic brain injury or stroke [5,6], frontotemporal dementia [7,8], Down syndrome [9], and Lewy body disease [10]. About $25 \%$ of the people in the U.S. are APOE4 carriers, and APOE4 is present in $65-80 \%$ of all AD patients. The presence of $A P O E 4$ increases the risk of developing AD by 4 -fold (one allele) to 14-fold (two alleles) compared with APOE3 homozygotes. APOE2 is considered neuroprotective, albeit with an increased risk of type III hyperlipoproteinemia [11,12]. The allelic combinations give rise to three homozygous (APOE2/2, APOE3/3, and APOE4/4) and three heterozygous (APOE2/3, APOE2/4, and $A P O E 3 / 4$ ) genotypes. Single point substitutions at amino acid residues 112 and 158 distinguish the three main apoE isoforms: apoE2 (Cys-112, Cys-158), apoE3 (Cys-112, Arg-158), and apoE4 (Arg-112, 
Arg-158) $[13,14]$. These substitutions result in structural differences that confer differential receptor and lipid binding abilities, and provide grounds to explain the physiological role of apoE isoforms in AD.

\section{Structures and Functions of apoE Isoforms}

ApoE is a glycoprotein that has two independently folded structural domains separated by an unstructured hinge region. The N-terminal domain (residues 1-191), which forms a four $\alpha$-helix bundle in which non-polar residues face the inside of the protein, harbors the sequences for binding to the members of the low-density lipoprotein (LDL) receptor family [15]. The C-terminal domain (residues 206-299), that harbors the major lipid binding region, presents a more relaxed structure with $\alpha$-helices generating a largely exposed hydrophobic surface [15]. The unstructured hinge regions provide a large degree of mobility, which is necessary for the protein to fulfill its primary function [15].

ApoE undergoes a profound conformational change upon lipid binding to accommodate and stabilize the lipids through its amphiphilic $\alpha$-helices [16]. Following lipid binding, apoE adopts a biologically active conformation that is necessary for its recognition and binding to the members of the LDL receptor family and its internalization [16]. The use of discoidal phospholipid-apoE particles or "nanodisks" have allowed a better understanding of the structure of lipid-bound apoE on some high density particles [16,17]. Lipid binding reorients the $\alpha$-helices of the C-terminal domain of apoE perpendicularly to the acyl chains of the lipids, circumscribing the edge of the nanodisks [17-19]. However, the conformational change on the $\mathrm{N}$-terminal domain has not converged towards a single model.

Calorimetry studies support a model in which the four-helix bundle opens leading to an extended conformation of apoE that wraps around the lipid bilayer of the disc $[20,21]$. By contrast, low resolution X-ray density and electron paramagnetic resonance favor a model in which apoE folds in a hairpin structure [22]. More recently, the combination of experimental techniques in molecular modeling and simulation support a model in which an open and compact hairpin conformation co-exist in a dynamic equilibrium, and the presence of receptor binding shifts the equilibrium towards the open hairpin conformation [17].

When analyzing the three apoE isoforms independently, X-ray crystallography measurements indicate that the Cys-158 at the N-terminal domain of apoE2 prevents receptor binding by changing the conformation of the lipid side chains residues 136-150 [12,13,23,24]. In apoE3, a salt bridge between Arg-158 and Asp-154 is formed, whereas in apoE4 it is disrupted. In apoE4, Asp-154 interacts with Arg-150, altering the receptor binding region. As a consequence of this new interaction, the side chain of Arg-61 is now in close proximity to Glu-255 in the C-terminal domain, allowing an ionic interaction between these two residues $[12,13,23,24]$. This interaction is less likely to happen in apoE2 and apoE3, because in these isoforms a structure is favored in which the Arg-61 is internal to the helical domain of the N-terminus $[12,13,23,24]$. A summary of the structural differences among apoE isoforms is depicted in Table 1.

Table 1. Structural differences among apolipoprotein E (apoE) isoforms.

\begin{tabular}{|c|c|c|}
\hline Isoform & Amino Acids $(112,158)$ & Structural Description \\
\hline ApoE2 & Cys, Cys & $\begin{array}{l}\text { - } \quad \text { Cys-158 at the N-terminal domain reduces receptor binding. } \\
\text { - } \quad \text { Arg-61 is internal to the helical domain of the N-terminus. } \\
\text { - } \quad \text { Ability to dimerize through cysteine-cysteine bonds, forming homodimers and multimers. }\end{array}$ \\
\hline ApoE3 & Cys, Arg & $\begin{array}{l}\text { - } \quad \text { Presence of salt bridge between Arg-158 and Asp-154. } \\
\text { - Arg-61 is internal to the helical domain of the N-terminus. } \\
\text { - } \quad \text { Ability to dimerize through a cysteine-cysteine bond, forming homodimers. }\end{array}$ \\
\hline ApoE4 & Arg, Arg & $\begin{array}{l}\text { - Asp-154 interacts with Arg-150, altering the receptor binding region. } \\
\text { - } \quad \text { Ionic interaction between Arg-61 and Glu-255 in the C-terminal domain. } \\
\text { - No cysteine residue. }\end{array}$ \\
\hline
\end{tabular}




\section{CNS apoE Protein}

In the CNS, apoE is synthesized in situ primarily by astrocytes, but also by microglia, oligodendrocytes, and to lesser extent injured neurons [25-29]. An additional source of apoE comes from the choroid plexus where apoE is rapidly delivered into the cerebrospinal fluid (CSF) and the brain via the glymphatic fluid transport, in an apoE isoform-dependent manner (apoE2 > apoE3 > apoE4) [30]. Peripheral apoE does not cross the blood-brain barrier (BBB), resulting in two separate pools of apoE, one in the periphery and one in the CNS.

The posttranslational modifications of apoE are different in the periphery and CNS [31,32]. In contrast to apoE in plasma, apoE in the CSF [31,33] and apoE secreted from astrocytes [34] are more heavily glycosylated and sialylated. CSF apoE is five times more glycosylated than plasma apoE [33]. Moreover, $A P O E$ genotype also affects the percentage of glycosylation in CSF [33]. APOE2 homozygotes have a higher percentage of glycosylated apoE in the CSF than APOE4 [33]. The biophysical properties of the protein changes with the addition of sialic groups, namely a reduction of the isoelectric point of apoE [35,36] and an altered solubility in brain tissue [37]. Compared to apoE3, apoE4 is more sialylated, evidenced by a shift in isoelectric point, and more solubility in tris buffered saline buffer [37].

Studies of apoE in the CSF and periphery have provided important information on the effects of $A P O E$ genotype on apoE production and secretion in the context of AD. Compared to APOE3, APOE4 carriers have reduced levels of apoE, whereas APOE2 carriers have elevated levels of apoE in the CSF and plasma [38]. This is in agreement with the effects of APOE genotype on apoE levels in brain parenchyma (apoE4 < apoE3 < apoE2), and in APOE targeted-replacement mice [39,40]. However, other studies show no differences in apoE levels among APOE genotypes in the CSF [41] or between AD patients and control subjects [42].

\section{Effects of apoE Isoforms on Cholesterol Synthesis and Transport/Efflux}

In the brain there are two major pools of CNS cholesterol. The first pool, which represents the vast majority of cholesterol (70-90\%), is found in the myelin sheaths of oligodendroglia that surrounds axons [43]. Cholesterol synthesis in the brain is highest in oligodendrocytes specially during periods of development [43]. In the mature brain, cholesterol synthesis continues at a lower rate. The second pool of cholesterol derives from plasma membranes of neurons and glia [43]. Astrocytes, which account for up to $50 \%$ of all brain cells in humans, provide the bulk of this second pool of cholesterol [44,45].

In astrocytes, cholesterol synthesis is tightly regulated by an internal feedback loop. If intracellular levels of cholesterol are low, an increase in cholesterol synthesis is promoted by proteolysis of sterol regulatory element-binding proteins (SREBPs), which increases cholesterol synthesis and endocytosis $[46,47]$. When the levels of intracellular cholesterol are high, transcription for cholesterol transport proteins is increased to enhance the efflux of lipids. This process is mediated by the liver $X$ receptors (LXRs) and the retinoid $X$ receptor (RXR) that belong to the type II family of nuclear receptors that undergo obligate heterodimerization [48]. The LXR/RXR heterodimer interacts with sequence-specific DNA elements positioned close to enhancers or promoters of their target genes, including the $A B C A 1, A B C G 1$, and $A P O E$, thus acting directly to upregulate their transcription (Figure 1A) $[48,49]$.

ApoE plays an integral role in maintaining lipid homeostasis. Mature neurons have a high demand for cholesterol and while they can synthesize it, under physiological conditions additional apoE-associated cholesterol is required $[45,46]$. ApoE initiates the formation of high-density lipoprotein (HDL)-like particles by accepting cholesterol and phospholipids through the activity members of the ATP-binding cassette (ABC) family of transporters, ABCA1 and ABCG1 (Figure 1B) [50]. $\mathrm{ABC}$ transporters use ATP to translocate a wide variety of substrates across extra- and intracellular membranes. The importance of ABCA1 in AD is discussed in more detail in Section 8.1 below. Less investigated in the context of $A D$ is the ABCG1 transporter. ABCG1 belongs to the G subfamily of the $A B C$ superfamily and is expressed in both neurons and astrocytes [51]. While CSF derived from $A B C G 1^{-} /$- mice has increased levels of amyloid $\beta(A \beta)_{(1-42)}$ compared to wild-type mice [51], 
overexpressing $A B C G 1$ did not alter the levels of $A \beta$, plaques, apoE levels, cholesterol efflux, or cognitive performance in mouse models of $\mathrm{AD}$ [52]. Thus, the ABCA1 and ABCG1 transporters differ somewhat in their involvement in $\mathrm{AD}$ pathogenic processes.

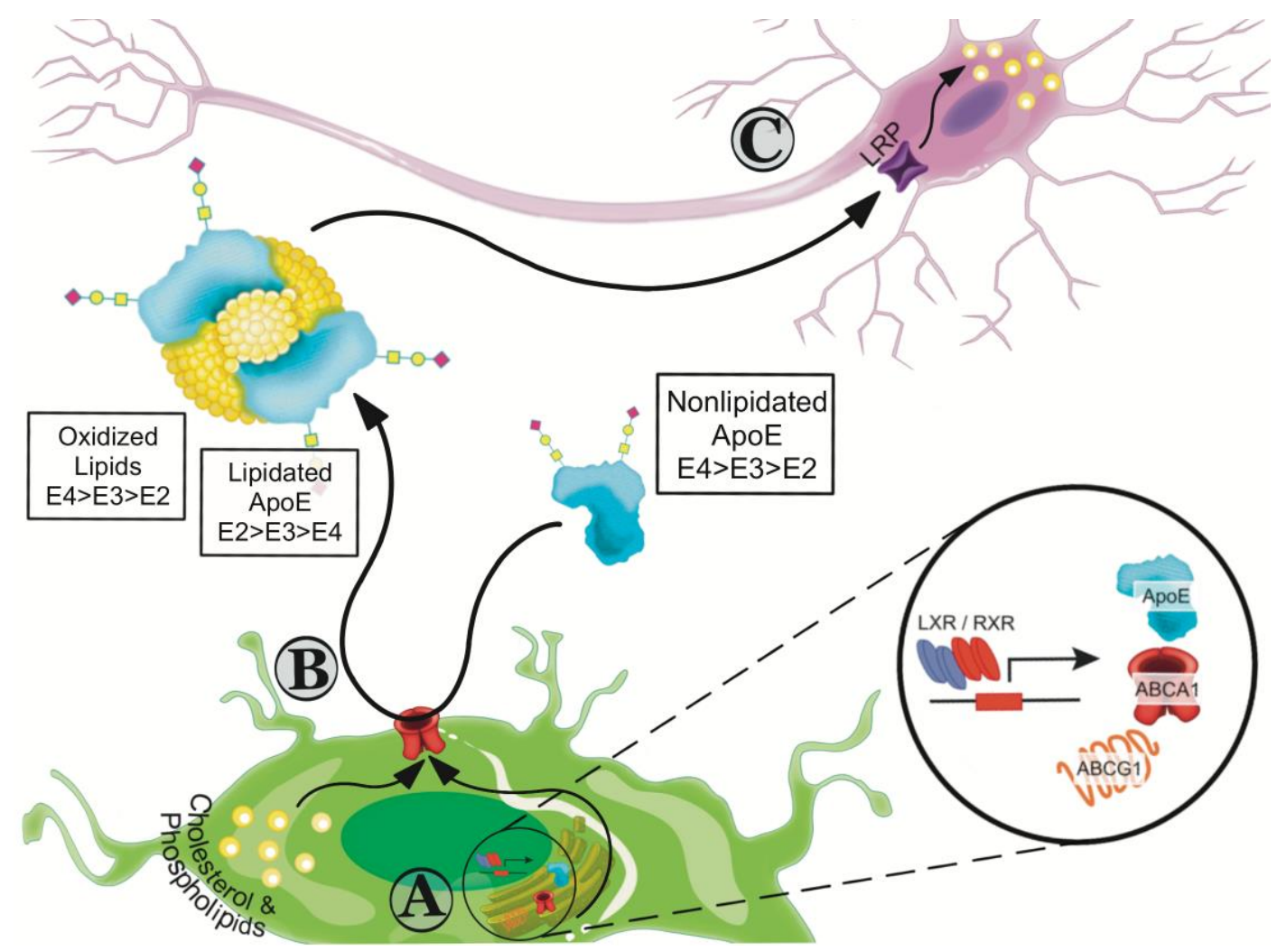

Figure 1. apoE and cholesterol transport and efflux. (A) In astrocytes, cholesterol synthesis is regulated by the liver $X$ receptors (LXRs) and the retinoid X receptor (RXR). The LXR/RXR heterodimer interacts with sequence-specific DNA elements positioned close to enhancers or promoters of their target genes, including the $A B C A 1, A B C G 1$, and $A P O E$, thus acting directly to upregulate their transcription. (B) apoE initiates the formation of high-density lipoprotein (HDL)-like particles by accepting cholesterol and phospholipids through the ABCA1 and ABCG1 transporters. (C) apoE-containing lipoproteins and lipid complexes interact with cell surface heparin sulfate proteoglycans and cell membrane associated receptors, including the LDL receptor and the LDL receptor-related protein 1 (LRP) in neurons. This interaction promotes cellular uptake and redistribution of cholesterol to maintain proper cellular function, including neuronal growth, repair and remodeling of membranes, organelle biogenesis, and synaptogenesis.

ApoE-containing lipoproteins and lipid complexes interact with cell surface heparin sulfate proteoglycan and cell membrane associated receptors, including the LDL receptor and the LDL receptor-related protein 1 (LRP1) in neurons (Figure 1C). This interaction promotes cellular uptake and redistribution of cholesterol/lipids and storage. Intracellular cholesterol is converted to oxysterols for clearance, a mechanism mediated in the CNS by cholesterol 24S-hydroxylase (CYP46A1) [53]. 24S-hydroxycholesterol can cross the BBB, enter the peripheral circulation and be eliminated as bile from the body [54].

Cholesterol and lipids are distributed to neurons and other brain cells in order to maintain proper cellular function, including neuronal growth, repair and remodeling of membranes, organelle biogenesis, and synaptogenesis [47,55-58]. Furthermore, CNS repair involves the interaction of apoE with lipid debris and degenerating membranes after injury [59]. 


\section{Effects of apoE Isoforms on Lipid Homeostasis}

Cholesterol homeostasis is vital for normal brain function, as $25 \%$ of all cholesterol in the body is found in the brain. The most recognized function of apoE is transport of cholesterol and other lipids, although apoE is also important in synaptic plasticity, signal transduction and immunomodulation [32,60-62]. Peripheral apoE is incorporated into lipoprotein particles in the plasma, and CNS apoE is incorporated into lipoprotein particles in the CSF and in the interstitial fluid of brain parenchyma [30,63].

An imbalance in cholesterol homeostasis is associated with an increased risk of neurodegenerative disorders such as AD, Huntington's disease (HD), Parkinson's disease (PD), Niemann-Pick type C disease (NPC), and Smith-Lemli Opitz syndrome (SLOS) [54]. In NPC, neurons sequester unesterified cholesterol and other lipids in late endosomes and/or lysosomes, leading to an unequal distribution of cholesterol between neuronal cell bodies and distal axons. As a result, there is a massive loss of neurons, particularly Purkinje cells in the cerebellum [54]. SLOS is caused by mutations in the gene encoding 7-dehydrocholesterol reductase, the enzyme that catalyzes the final step in the cholesterol biosynthetic pathway, thus causing an elevation of the potentially toxic cholesterol precursor, 7-dehydrocholesterol, and a reduction in cholesterol in cells [54]. In HD, in which striatal and cortical neurons are particularly susceptible to the toxic mutant huntingtin protein, the cholesterol biosynthetic pathway is markedly altered [64]. Expression of mutant huntingtin in neurons downregulate the expression of SREBP-1, the regulator of the cholesterol biosynthetic pathway, thus reducing the levels of cholesterol in the cell [64]. Addition of cholesterol to striatal neurons expressing mutant huntingtin increased their survival, suggesting that the deficit in cholesterol contributes directly to the neurological phenotype of HD [54,64]. Cellular cholesterol accumulation can lead to cytotoxicity, inflammation and alteration of plasma membrane composition [54], whereas cholesterol depletion can lead to synaptic and dendritic spine degeneration, failed neurotransmission, and decreased synaptic plasticity [43].

Due to their structural differences, apoE isoforms exhibit differential abilities of binding/transporting cholesterol and phospholipids. ApoE2 is the most efficient isoform in promoting cholesterol efflux from cells compared to apoE3, and apoE3 is more efficient compared to apoE4 [65-67]. APOE2 homozygotes exhibit defective binding to LDL receptors, and thus these individuals may experience type III hyperlipoproteinemia and premature atherosclerosis, especially in the presence of other conditions such as diabetes, obesity, hypothyroidism or estrogen deficiency. The overproduction of very low-density lipoprotein (VLDL), or the presence of fewer LDL receptors, overwhelms the limited ability of apoE2 to mediate the clearance of triglyceride- and cholesterol-rich $\beta$-VLDL in plasma [12].

Cholesterol accumulation in APOE4 astrocytes is not only due to reduced apoE levels, but also to a dysregulated expression of genes involved in lipid metabolism, such as cholesterol biosynthesis-related genes and to impaired lysosomal cholesterol degradation processes [68,69]. Abnormal cholesterol metabolism by APOE4 astrocytes would result in altered cholesterol transport to other cell-types and functional deficits in neurons [70]. APOE4 homozygotes have elevated cholesterol levels in the plasma and increased 24S-hydroxycholesterol in the CSF [71,72]. ApoE4 is associated with smaller lipoproteins [73]. ApoE4-containing lipoproteins promote less cholesterol efflux than apoE3-containing lipoproteins [73]. Moreover, APOE4 carriers have more lipid-depleted lipoproteins in their CSF than APOE4-negative individuals [74,75]. Thus, APOE4 genotype has profound effects on lipid metabolism, transport and homeostasis.

Intracellular accumulation of lipids in lipid droplets is central to cellular lipid homeostasis, and APOE allele-dependent [76,77]. APOE4 astrocytes accumulate more and in smaller lipid droplets compared to APOE3 astrocytes [76]. Lipid droplets serve two purposes: First, to sequester free fatty acids that may be cytotoxic in the cytoplasm; and second, become an energy rich storage pool for cellular metabolic needs [76]. In neurons, elevation of ROS results in increased levels of peroxidized lipids, which may cause a disruption in lipid homeostasis, mitochondrial dysfunction and neuronal toxicity. A mechanism used by neurons to mitigate this toxicity is to transfer the burden of lipid 
accumulation and subsequent clearance to astrocytes [77]. The lipid accumulates inside neighboring astrocytes as lipid droplets, a process that is considered neuroprotective [77].

Additionally, APOE genotype is associated with susceptibility to oxidative stress and lipid peroxidation, and it is observed earlier in the progression of $\mathrm{AD}[78,79]$. APOE4 carriers with AD pathology presented higher levels of oxidative stress and elevated lipid peroxidation in a brain area-specific manner compared to APOE3 homozygotes [79,80]. Furthermore, synaptosomes isolated from human $A P O E 4$ targeted-replacement mice presented higher levels of reactive oxygen species (ROS) and lipid oxidation compared to APOE3, and APOE3 compared to APOE2 [81].

ApoE2 and apoE3 bind more lipid peroxidation products than apoE4, a mechanism dependent on the number of cysteine residues in the protein $[78,79,82]$ (Table 1). ApoE keeps these neurotoxic agents from damaging neuronal proteins, but since apoE4 lacks these residues, lipid peroxidation products affect the integrity of neuronal proteins [82]. Together, these results reflect the importance of apoE as a modulator of oxidative stress and lipid peroxidation in cells.

\section{Effects of apoE Isoforms on Lipidation}

ApoE must be secreted and properly lipidated in order to perform its normal functions, such as lipid/cholesterol transport, synapse regeneration, immune modulation, and clearance/degradation of $A \beta$ [83-85]. ApoE4 is poorly lipidated and expressed in lower levels compared with apoE2 and apoE3 $[83,84,86,87]$. The apoE function and receptor binding capacity are dependent on the lipidation status of apoE [88], as key residues involved in receptor binding become unburied when apoE is lipidated [15]. The deficiency of apoE4 lipidation suggests that increasing the lipidation of apoE in general may be a viable therapeutic avenue for $\mathrm{AD}$ and other neurological disorders.

Biophysical studies using lipid-free apoE and HDL-like discoidal apoE particles of all three apoE isoforms showed that lipid-free apoE has the tendency to aggregate in vitro in an isoform-dependent manner (apoE4 > apoE3 > apoE2), and lipidation of apoE impedes the formation of aggregates [89]. Lipid-free apoE oligomerizes through a monomer-dimer-tetramer association process [90] but also assembles into higher molecular weight aggregates [91,92]. Higher levels of aggregation of apoE4 might contribute to its toxic effects to neuronal cells.

Lipidated apoE structures vary with apoE isoform. ApoE2 is associated with larger lipoprotein complexes [84]. APOE2/3 individuals have largest apoE complexes in the CSF compared to APOE4 heterozygote individuals. Based on nondenaturing gel electrophoresis, the CSF of APOE2 carriers have a continuum of lipid complexes between 720 and $480 \mathrm{kDa}$, while APOE4 carriers have smaller complexes with an average of $<500 \mathrm{kDa}$ [86]. ApoE4 forms smaller lipid complexes in both wild-type mouse brains $[84,93,94]$, and mouse brains transfected with viral-expressing different ApoE isoforms [84,95]. Lipidated apoE from human APOE3 or APOE4 iPSC-derived astrocytes, assessed by nondenaturing gel electrophoresis, was characterized by large ( $>669 \mathrm{kDa})$, medium $(440-669 \mathrm{kDa})$ and small particles $(<440 \mathrm{kDa})$ [96]. While the population of large apoE particles was not affected by genotype, APOE4 astrocytes secreted less middle size and more smaller size particles compared to APOE3, providing more data that apoE4 particles are less lipidated [96].

The major lipids found in apoE-containing CNS particles are free cholesterol, phospholipids and triglycerides [97]. ApoE4 particles are associated with less cholesterol than apoE3 [94,96]. ApoE3 particles contain three times more total cholesterol levels per microgram of apoE protein than apoE4 particles [94]. In contrast, triglycerides are present at higher levels in apoE4-containing particles compared with apoE3 particles [97].

Cholesterol is one of the major components of cellular membranes and acts to make membranes more fluid and to decrease membrane permeability to hydrophilic molecules [98]. Importantly, cholesterol is rich in lipid rafts which are essential domains involved in signal transduction, neuronal cell adhesion, axon guidance and synaptic transmission. Cholesterol is increasingly linked to $\mathrm{AD}$ pathology. In cultured neurons, transient membrane cholesterol increase results in $A \beta_{(1-42)}$ overproduction, endosomal enlargement, axonal transport abnormalities, and gene expression changes 
that are reminiscent of early stages of AD [99]. Replacing membrane cholesterol with stigmasterol, a plant sterol that crosses the BBB, decreased amyloid precursor protein (APP) processing and the production of $A \beta$ peptides in mice [100]. Cholesterol is highly enriched in myelin sheaths and allows the propagation of nerve impulses by saltatory mechanisms. Lower concentrations of phosphatidylinositol and sphingomyelin and a higher concentration of phosphatidylcholine are present in synaptosomal low-density membrane fractions from APOE4/APP mice compared to APOE3/APP mice [101].

This difference in the size and composition of lipoprotein particles associated with APOE4 genotype could translate into less lipid delivery to cells for membrane synthesis or other cellular functions and less lipid clearance from some locations, compromising neuronal health.

\section{Recalibrating apoE Functions by Increasing Lipidation}

Improving the lipidated state of apoE ameliorates cognitive deficits in the presence or absence of amyloid pathology regardless of $A P O E$ genotype $[73,102,103]$. In this section we will discuss possible ways of increasing the lipidation of apoE (Figure 2, Table 2).

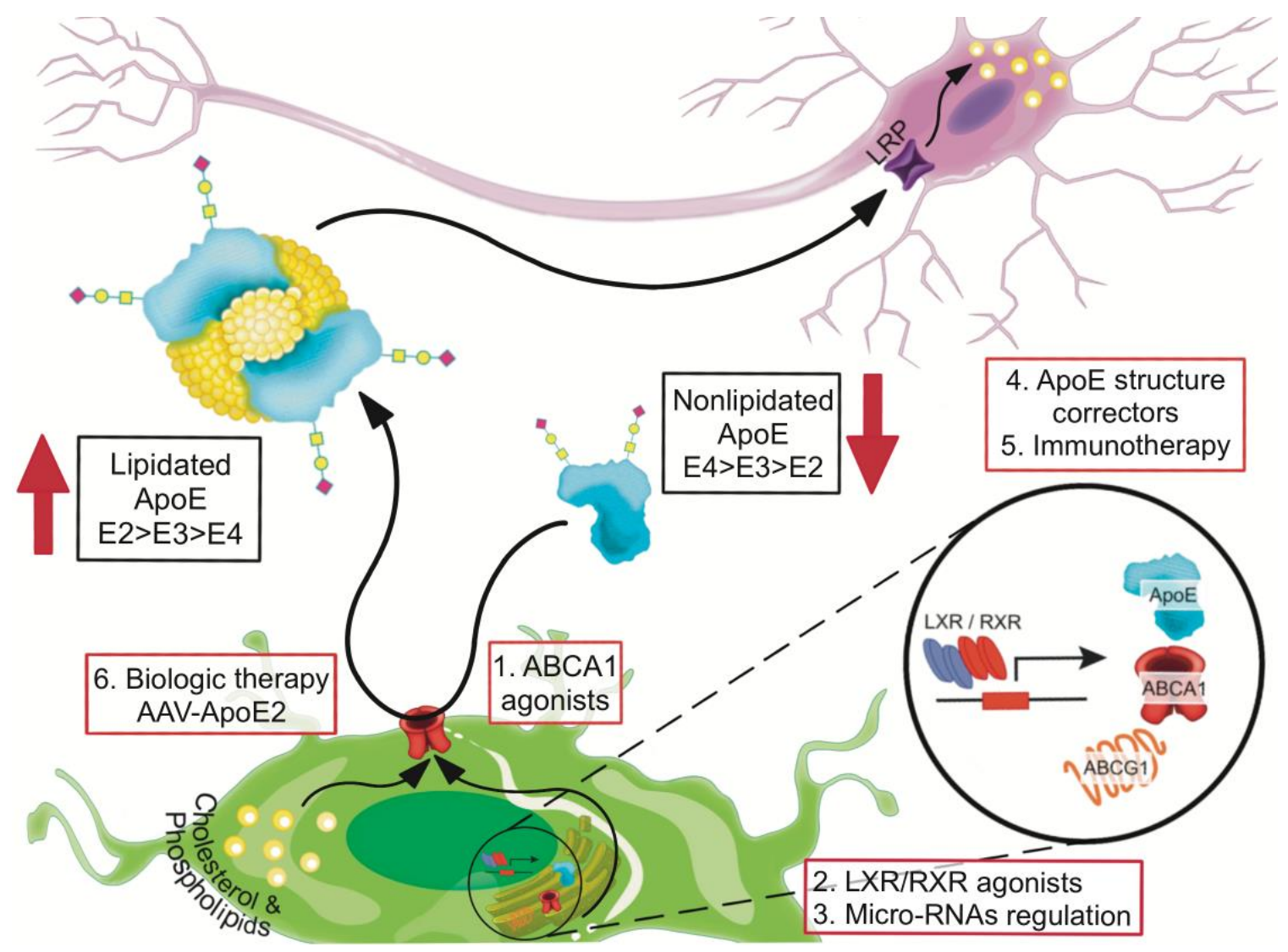

Figure 2. Recalibrating apoE functions by increasing lipidation. Therapeutic strategies to improve the lipidated state of apoE include the use of: (1) Small molecules that enhance ABCA1 activity, (2) Liver X receptor (LXR) and retinoid X receptor (RXR) agonists to increase the expression of $A B C A 1, A B C G 1$ and $A P O E$, (3) regulation of micro-RNAs to increase ABCA1 expression, (4) small molecules as apoE4 structure correctors, (5) anti-apoE4 immunotherapy targeting non-lipidated apoE, and (6) recalibrating apoE function by using AAV-APOE2 biologic therapy. 
Table 2. Therapeutic approaches to recalibrate apoE functions by increasing lipidation.

\begin{tabular}{|c|c|c|c|}
\hline Class & Description & Example & References \\
\hline \multirow{5}{*}{ ABCA1 agonist } & \multirow{2}{*}{ Antisense oligonucleotides } & miR-33 & [104] \\
\hline & & ARF6 & [105] \\
\hline & \multirow{3}{*}{ Small peptides } & CS-6253 & [73], [106,107] \\
\hline & & Ac-hE18A-NH2 & [108] \\
\hline & & $4 \mathrm{~F}$ & [73], [109-111] \\
\hline \multirow{5}{*}{ Nuclear Receptor agonist } & \multirow{2}{*}{ LXR agonist } & TO901317 & [112-114] \\
\hline & & GW3965 & [112-114] \\
\hline & \multirow{3}{*}{ RXR agonist } & Bexarotene & [115-119] \\
\hline & & LG100268 & [115-117] \\
\hline & & SPF1 and SPF2 & {$[120,121]$} \\
\hline \multirow{2}{*}{ Structure corrector } & Small molecule that corrects & PH002 & [122] \\
\hline & apoE4 structure & GIND105 and GIND-25 & [123-125] \\
\hline Immunotherapy & Targets non-lipidated apoE4 & HAE- 1 and HAE- 4 & {$[126,127]$} \\
\hline Biologics & AAV-directed therapy & $\begin{array}{l}\text { AAV-expressing human } \\
\text { APOE2 gene }\end{array}$ & [84], [128-131] \\
\hline
\end{tabular}

\subsection{Small Molecules that Enhance ABCA1-Mediated apoE4 Lipidation}

The ABCA1 transporter transfers cholesterol from cells onto lipid-poor apolipoproteins and regulates apoE lipidation in the brain [88]. Reduced amyloid deposition and improved $A \beta$ clearance have been observed in an AD mouse model after overexpressing ABCA1 transporter [132,133], whereas deletion of the $A B C A 1$ gene decreases levels of apoE protein $[134,135]$ and increases the deposition of $\mathrm{A} \beta[88,135-137]$. Studies of brain tissue, CSF, plasma, and primary astrocyte cultures from $\mathrm{ABCA} 1^{+} /+$, $\mathrm{ABCA} 1^{+} /-$, and $\mathrm{ABCA} 1^{-} /-$mice showed that deletion of ABCA1 markedly affects metabolism of apoE and cholesterol in the CNS and in nascent lipoprotein particles secreted by cultured astrocytes [132]. Loss-of-function mutations in ABCA1 are associated with low plasma levels of apoE [138]. AD and mild cognitive impaired individuals have $30 \%$ less ABCA1-mediated cholesterol efflux capacity toward CSF than healthy individuals; this effect was APOE genotype-independent [139]. In addition, lipidation of apoE-containing lipoproteins in the brain may act independently of $A \beta$ metabolism by protecting the integrity of the BBB and maintaining normal cerebrovascular function [140].

One approach to increasing the activation of the ABCA1 transporter is through regulation of micro-RNA expression. Overexpression of micro RNA-33 (miR-33), which is highly expressed throughout the brain and most abundantly in neurons, impairs cellular cholesterol efflux and increases extracellular $A \beta$ levels by promoting $A \beta$ secretion and impairing $A \beta$ clearance [104]. In contrast, deletion of miR-33 in mice increases ABCA1 levels and apoE lipidation, while decreasing endogenous $A \beta$ levels in cortex. Importantly, pharmacological inhibition of miR-33 via antisense oligonucleotide targeted to the brain decreases $\mathrm{A} \beta$ levels in cortex of APP/PS1 mice [104]. Cortex of mir-33-deficient mice, compared with wild-type mice, contains increased levels of ABCA1 protein and larger apoE-containing lipoproteins, suggesting that miR-33 plays a dominant role in regulating ABCA1 expression and apoE lipidation under normal physiological conditions [104].

A second approach is through the use of small peptides based on the C-terminal domain of apoE as ABCA1 agonists with therapeutic potential [106]. The peptide CS-6253 enhanced lipid efflux through ABCA1 allowing the generation of apoE3-like lipoproteins in young APOE4-targeted replacement mice [106]. CS-6253 ameliorated APOE4-driven cognitive and brain pathologies through activation of ABCA1 [73]. This effect was associated with a reversal of the apoE4-driven $A \beta_{(1-42)}$ accumulation and tau hyperphosphorylation in hippocampal neurons, as well as of the synaptic impairments and cognitive deficits associated with APOE4 phenotype [107].

A second peptide with therapeutic potential is Ac-hE18A-NH2, a hybrid apoE/apoA-I-mimetic peptide. Ac-hE18A-NH2 ameliorated the inhibitory effects of $A \beta_{(1-42)}$ on secretion of apoE in U251 astrocyte cell line [108]. In vivo administration of Ac-hE18A-NH2 to APP/PS1 $\triangle E 9$ mice for six weeks 
improved cognition, decreased amyloid plaque deposition, reduced activated microglia and astrocytes, and increased CNS apoE levels [108].

Another small peptide is $4 \mathrm{~F}$, which consists of 18 amino acids containing four phenylalanine residues that mimic HDL function. $4 \mathrm{~F}$ induces a selective and robust concentration- and time-dependent increase in apoE secretion and lipidation in primary human astrocytes and in primary murine glial cells, without causing cell death [109]. These observed effects were dependent on the presence of the ABCA1 transporter. Co-treatment with $4 \mathrm{~F}$ counteracts the inhibitory effects of $\mathrm{A} \beta$ on both apoE secretion and lipidation in primary mouse and human astrocytes [109]. Furthermore, 4F has been tested in three human clinical trials for cardiovascular disease: $4 \mathrm{~F}$ improved HDL anti-inflammatory properties, and was found to be safe and well-tolerated when administered orally or by injections [110,111].

ApoE lipidation could also be affected by other molecules that alter ABCA1 activity. ABCA1 recycling and degradation is regulated by ADP-ribosylation factor 6 (ARF6). ApoE4 promotes greater expression of ARF6 compared with apoE3, trapping ABCA1 in late-endosomes and impairing its recycling to the cell membrane, thus lowering ABCA1-mediated cholesterol efflux activity. Reduced ABCA1 activity increases the prevalence of lipid-free apoE particles, and lowers A $\beta$ degradation capacity [105]. Thus, regulating the expression of ARF6 with antisense oligonucleotides in a way that favors the recycling of ABCA1 may also be beneficial for APOE4 carriers.

\subsection{Liver X Receptor (LXR) and Retinoid X Receptor (RXR) Agonists}

Nuclear receptor agonists upregulate $A B C A 1, A B C G 1$, and $A P O E$ gene expression, which increases apoE lipidation, facilitates $A \beta$ clearance, reduces amyloid pathology, and reverses memory deficits in an amyloid mouse model $[49,103,116]$. Bexarotene and LG100268 are RXR agonists that promote dimerization and activation of both LXRs and peroxisome proliferator-activated receptor-gamma (PPAR- $\gamma)$, resulting in the increase of apoE lipidation and ABCA1 expression in AD animal models [115-117]. In vitro and in vivo studies show that bexarotene suppresses inflammation and astrogliosis, activates microglial phagocytosis, and improves neuronal survival, differentiation and neuronal projections $[118,119]$. The effects of bexarotene on soluble $A \beta_{(1-40)}$ and $A \beta_{(1-42)}$ levels and plaque deposition are dependent on the presence of both $A P O E$ and $A B C A 1[112,115]$.

In addition, two prenylated flavanoids isolated from the root of Sophora tonkinensis (SPF1 and SPF2) have selective RXR agonist activity and promote ABCA1 upregulation, thus promoting apoE lipidation $[120,121]$. They protect differentiated PC12 cells from A $\beta$-induced neurotoxicity. When given in combination with the LXR agonist T0901317, these effects are markedly enhanced [120]. SPF1 and SPF2 also suppresses the cytokine production of IL-1 $\beta$, IL-6, and TNF- $\alpha$ in vitro [121].

LXR activation by T0901317 or GW3965 altered A $\beta$ production in neuronal and non-neuronal cells in vitro and in vivo [114,141]. Short-term administration of T0901317 or GW3965 improved fear conditioning behavioral outcomes, increased apoE lipidation, and promoted the association of microglia with $A \beta$ plaques. Long-term administration treatment restored object recognition and reduced plaque formation by $50 \%$ in mouse models of $\mathrm{AD}$ [112-114].

Although nuclear receptor agonists may be promising therapeutic targets for $\mathrm{AD}$, they produce unwanted peripheral effects on triglyceride production and liver health [142-144]. LXR activation induces the expression of genes associated with lipogenesis, a mechanism mediated by the induction of transcription factors such as the carbohydrate-response element-binding protein (ChREBP), PPAR- $\gamma$, and the SREBP-1 [143,144]. Moreover, LXRs regulate enzymes involved in the biosynthesis of saturated or monounsaturated fatty acids (e.g., acetyl-CoA carboxylase, fatty acid synthase, steroyl-CoA desaturase), thus increasing the levels of triglyceride and phospholipid in the liver in different animal models, leading to hepatic steatosis, stimulation of VLDL secretion and elevated plasma triglyceride levels [144]. Hepatic steatosis was also observed in human clinical trials, limiting the therapeutic development of synthetic LXR agonists [144]. It is possible that CNS-specific LXR activation could be useful while avoiding side effects in the periphery. 


\subsection{Small Molecules as apoE4 Structure Correctors}

Structure correctors could prevent the apoE4-associated neuropathology by changing the conformation of apoE4 into an apoE3-like structure, thus allowing proper lipidation of the apoE protein and greater transport of phospholipids and cholesterol [12]. As mentioned in Section 7, apoE4 is more easily self-aggregated, thus reducing its lipidation capacity. The use of apoE4 structure correctors would reduce apoE aggregation and facilitate apoE lipidation, becoming an appealing therapeutic potential for AD treatment. ApoE4 is also targeted for degradation more readily than apoE3, perhaps due to its altered folding [39]. ApoE4 is recognized by neuron-specific proteases generating neurotoxic C-terminal fragments [145]; structure correctors could diminish the production of these neurotoxic fragments.

A cellular fluorescence resonance energy transfer (FRET) assay has been used for the identification of small-molecule structure correctors to identify molecules that block the ionic interaction between Arg-61 and Glu-255. ApoE4 labeled at the N-terminus with green fluorescent protein and the C-terminus with Escherichia coli dihydrofolate reductase [122,146] allowed identification of small-molecule structure correctors to prevent FRET emission signal that occurs when the $\mathrm{N}$-terminal and the C-terminal of apoE4 are in close proximity. The experimental compound PH002 was identified that dose-dependently mitigated the toxic effect of apoE4 in neurons derived from human iPSCs by decreasing the levels of apoE4 fragments, increasing GABAergic neuron numbers and GAD67 levels, reducing hyperphosphorylated tau levels, and decreasing the levels of $A \beta_{(1-40)}$ and $A \beta_{(1-42)}$ production and/or secretion [122]. Two other compounds, GIND-25 and GIND105, were also designed to restore apoE4 to an apoE3-like protein with respect to its lipid-binding characteristics and its effects on cultured neurons [123-125].

\subsection{Anti-apoE4 Immunotherapy}

Introduction or generation of antibodies against the non-lipidated form of apoE4 could reduce toxic effects of non-lipidated apoE4. Non-lipidated apoE4 protein has a greater tendency to aggregate than non-lipidated apoE3 [126], and lipidating apoE ex vivo reduces apoE aggregation [89]. Targeting a specific conformational form of non-lipidated apoE reduces A $\beta$ pathology in mouse models of AD [127]. The anti-human apoE antibody HAE-4 (HAE-4), that specifically recognizes human apoE4 and apoE3, preferentially binds non-lipidated as compared to lipidated apoE [127]. When delivered centrally (injection or adeno-associated virus) or peripherally, HAE-4 preferentially binds to apoE aggregates, and reduces $\mathrm{A} \beta$ deposition and $\mathrm{A} \beta$ accumulation in the brain of APP/PS1-21/APOE4 mice without altering levels of total apoE in plasma, CSF, or the extracellular space of the brain [127]. Antibodies mediating a protective effect by targeting aggregated or non-lipidated apoE in plaques and inciting microglial response, leading to clearance, is a promising approach for treating AD.

\subsection{Recalibrating apoE Function by Using AAV-APOE2 Biologic Therapy}

Individuals homozygotes for the APOE4 allele have the highest risk of developing AD. On the other hand, the presence of the APOE2 allele, markedly reduces the risk of developing late-onset AD. Based on this genetic data, it was hypothesized that expressing the protective APOE2 allele by genetically modifying the CNS of APOE4 homozygotes, converting them into APOE2/4 heterozygotes, could reverse or prevent the progression of the disease. Since apoE2 is associated with larger lipoproteins than apoE3 and apoE4 (Section 7, "Effects of apoE isoforms on lipidation"), this approach would introduce more lipidated forms of apoE to at-risk individuals. AAV delivery of APOE2 into the CSF of the lateral ventricle of mice overexpressing mutant APP or APP/PS1/APOE4 transgenes showed protective effect against the pathology associated apoE4 expression [128,129]. Nondenaturing gel electrophoresis demonstrated that APOE2 expressed by the AAV vector was lipidated [130], as previously reported for endogenous apoE [131]. Moreover, three routes of AAV delivery (intraparenchymal, intraventricular, and intracisternal) of the APOE2 gene to the CNS in non-human primates were compared and showed 
to be both efficacious and safe, resulting in therapeutic levels of apoE2 in the CSF ( $>1 \mu \mathrm{g} / \mathrm{mL}$ ) [128] (human and rodent apoE levels in the CSF are 1-5 $\mathrm{gg} / \mathrm{mL}$ [147]). Lastly, intracerebroventricular injection of AAV vectors expressing APOE2 in the APOE4 transgenic mice enhanced apoE lipidation, increased levels of apoE-associated cholesterol, and decreased endogenous A $\beta$ [84]. Conversely, apoE4 overexpression in $A P O E 4$ transgenic mice increased poorly-lipidated apoE lipoprotein particles and levels of endogenous $A \beta$, and decreased levels of apoE-associated cholesterol [84].

\section{Concluding Remarks}

ApoE is the main lipid carrier in the CNS and the current evidence highlights the importance of $A P O E$ isoforms in modulating the pathogenesis of $\mathrm{AD}$. ApoE isoforms not only affect $\mathrm{A} \beta$ clearance and aggregation, but also neuronal growth, repair and remodeling of membranes, synaptogenesis, and neuroinflammation. Here we highlight therapeutic approaches targeted to APOE lipidation, which have the potential to correct or prevent several outcomes associated with neurodegeneration. Many of these approaches have been validated using diverse cellular and animal models. APOE-targeted therapies may be more effective at preventing AD rather than treating existing $\mathrm{AD}$ and neurodegeneration. The benefits of increasing lipidation and decreasing lipid-free availability might be more beneficial with APOE4 carriers, which account for large percentages of control and AD populations. Current genotyping technologies and platforms promote access to information about the predisposition of an individual to $\mathrm{AD}$ at very early ages, thus allowing preventive treatments for high risk populations throughout life. These APOE-targeted therapies need also to take into account effects of altering apoE and lipid homeostasis in the periphery. The data discussed herein point towards a therapeutic model in which increasing lipidation, while simultaneously decreasing lipid-free apoE by a combined therapy, would be an appealing approach to ameliorate or prevent AD.

Author Contributions: M.F.L. writing—original draft preparation, C.A.N.; writing-review and editing, figures preparation G.W.R.; writing - original draft preparation, review and editing. All authors have read and agreed to the published version of the manuscript.

Funding: This work was supported by NIH R01 NS100704 and R01 AG067258.

Conflicts of Interest: The authors declare no conflict of interest. G.W.R. is a member of the APOE Scientific Advisory Board at Biogen.

\section{Abbreviations}

$\begin{array}{ll}\text { AD } & \text { Alzheimer's disease } \\ \text { ABCA1 } & \text { ATP-binding cassette transporter A1 } \\ \text { ABCG1 } & \text { ATP-binding cassette transporter G1 } \\ \text { apoE } & \text { Apolipoprotein E protein } \\ \text { APOE } & \text { Apolipoprotein E gene } \\ \text { APP } & \text { Amyloid precursor protein } \\ \text { ARF6 } & \text { ADP-ribosylation factor } 6 \\ \text { A } \beta & \text { Amyloid } \beta \\ \text { BBB } & \text { Blood-brain barrier } \\ \text { CNS } & \text { Central nervous system } \\ \text { CSF } & \text { Cerebrospinal fluid } \\ \text { CYP46A1 } & \text { Cholesterol 24S-hydroxylase } \\ \text { FRET } & \text { Fluorescence resonance energy transfer } \\ \text { HD } & \text { Huntington's disease } \\ \text { HDL } & \text { High-density lipoprotein } \\ \text { LDL } & \text { Low-density lipoprotein } \\ \text { LRP } & \text { LDL receptor-related protein } \\ \text { LXR } & \text { Liver X receptors } \\ \text { NCP } & \text { Niemann-Pick type C } \\ \text { PD } & \text { Parkinson's disease }\end{array}$


PPAR- $\gamma$ Peroxisome proliferator-activated receptor- $\gamma$

ROS Reactive Oxygen Species

RXR Retinoid X receptor

SLOS Smith-Lemli Opitz syndrome

SREBP-1 Sterol regulatory element-binding proteins

VLDL Very-low-density lipoprotein

\section{References}

1. Strittmatter, W.J.; Saunders, A.M.; Schmechel, D.; Pericak-Vance, M.; Enghild, J.; Salvesen, G.S.; Roses, A.D. Apolipoprotein E: High-avidity binding to beta-amyloid and increased frequency of type 4 allele in late-onset familial Alzheimer disease. Proc. Natl. Acad. Sci. USA 1993, 90, 1977-1981. [CrossRef] [PubMed]

2. Corder, E.H.; Saunders, A.M.; Strittmatter, W.J.; Schmechel, D.E.; Gaskell, P.C.; Small, G.W.; Roses, A.D.; Haines, J.L.; Pericak-Vance, M.A. Gene dose of apolipoprotein E type 4 allele and the risk of Alzheimer's disease in late onset families. Science 1993, 261, 921-923. [CrossRef] [PubMed]

3. Heffernan, A.L.; Chidgey, C.; Peng, P.; Masters, C.L.; Roberts, B.R. The Neurobiology and Age-Related Prevalence of the epsilon4 Allele of Apolipoprotein E in Alzheimer's Disease Cohorts. J. Mol. Neurosci. 2016, 60, 316-324. [CrossRef] [PubMed]

4. Fernandez, C.G.; Hamby, M.E.; McReynolds, M.L.; Ray, W.J. The Role of APOE4 in Disrupting the Homeostatic Functions of Astrocytes and Microglia in Aging and Alzheimer's Disease. Front. Aging Neurosci. 2019, 11, 14. [CrossRef]

5. Tensaouti, Y.; Yu, T.S.; Kernie, S.G. Apolipoprotein E regulates the maturation of injury-induced adult-born hippocampal neurons following traumatic brain injury. PLoS ONE 2020, 15, e0229240. [CrossRef]

6. McFadyen, C.A.; Zeiler, F.A.; Newcombe, V.; Synnot, A.; Steyerberg, E.; Gruen, R.L.; Rosand, J.; Palotie, A.; Maas, A.I.R.; Menon, D.K. Apolipoprotein E4 Polymorphism and Outcomes from Traumatic Brain Injury: A Living Systematic Review and Meta-Analysis. J. Neurotrauma 2019. [CrossRef]

7. Agosta, F.; Vossel, K.A.; Miller, B.L.; Migliaccio, R.; Bonasera, S.J.; Filippi, M.; Boxer, A.L.; Karydas, A.; Possin, K.L.; Gorno-Tempini, M.L. Apolipoprotein E epsilon4 is associated with disease-specific effects on brain atrophy in Alzheimer's disease and frontotemporal dementia. Proc. Natl. Acad. Sci. USA 2009, 106, 2018-2022. [CrossRef]

8. Borroni, B.; Perani, D.; Archetti, S.; Agosti, C.; Paghera, B.; Bellelli, G.; Di Luca, M.; Padovani, A. Functional correlates of Apolipoprotein E genotype in Frontotemporal Lobar Degeneration. BMC Neurol. 2006, 6, 31. [CrossRef]

9. Raha-Chowdhury, R.; Henderson, J.W.; Raha, A.A.; Vuono, R.; Bickerton, A.; Jones, E.; Fincham, R.; Allinson, K.; Holland, A.; Zaman, S.H. Choroid Plexus Acts as Gatekeeper for TREM2, Abnormal Accumulation of ApoE, and Fibrillary Tau in Alzheimer's Disease and in Down Syndrome Dementia. J. Alzheimers Dis. 2019, 69, 91-109. [CrossRef]

10. Prokopenko, I.; Miyakawa, G.; Zheng, B.; Heikkinen, J.; Petrova Quayle, D.; Udeh-Momoh, C.; Claringbould, A.; Neumann, J.; Haytural, H.; Kaakinen, M.A.; et al. Alzheimer's disease pathology explains association between dementia with Lewy bodies and APOE-epsilon4/TOMM40 long poly-T repeat allele variants. Alzheimers Dement. 2019, 5, 814-824.

11. Mahley, R.W. Apolipoprotein E: Remarkable Protein Sheds Light on Cardiovascular and Neurological Diseases. Clin. Chem. 2017, 63, 14-20. [CrossRef] [PubMed]

12. Mahley, R.W. Apolipoprotein E: From cardiovascular disease to neurodegenerative disorders. J. Mol. Med. 2016, 94, 739-746. [CrossRef] [PubMed]

13. Mahley, R.W.; Rall, S.C., Jr. Apolipoprotein E: Far more than a lipid transport protein. Annu. Rev. Genom. Hum. Genet. 2000, 1, 507-537. [CrossRef] [PubMed]

14. Zannis, V.I.; Breslow, J.L.; Utermann, G.; Mahley, R.W.; Weisgraber, K.H.; Havel, R.J.; Goldstein, J.L.; Brown, M.S.; Schonfeld, G.; Hazzard, W.R.; et al. Proposed nomenclature of apoE isoproteins, apoE genotypes, and phenotypes. J. Lipid Res. 1982, 23, 911-914.

15. Chen, J.; Li, Q.; Wang, J. Topology of human apolipoprotein E3 uniquely regulates its diverse biological functions. Proc. Natl. Acad. Sci. USA 2011, 108, 14813-14818. [CrossRef] 
16. Hauser, P.S.; Narayanaswami, V.; Ryan, R.O. Apolipoprotein E: From lipid transport to neurobiology. Prog. Lipid Res. 2011, 50, 62-74. [CrossRef]

17. Henry, N.; Krammer, E.M.; Stengel, F.; Adams, Q.; Van Liefferinge, F.; Hubin, E.; Chaves, R.; Efremov, R.; Aebersold, R.; Vandenbussche, G.; et al. Lipidated apolipoprotein E4 structure and its receptor binding mechanism determined by a combined cross-linking coupled to mass spectrometry and molecular dynamics approach. PLoS Comput. Biol. 2018, 14, e1006165. [CrossRef]

18. Raussens, V.; Drury, J.; Forte, T.M.; Choy, N.; Goormaghtigh, E.; Ruysschaert, J.M.; Narayanaswami, V. Orientation and mode of lipid-binding interaction of human apolipoprotein E C-terminal domain. Biochem. J. 2005, 387, 747-754. [CrossRef]

19. Narayanaswami, V.; Maiorano, J.N.; Dhanasekaran, P.; Ryan, R.O.; Phillips, M.C.; Lund-Katz, S.; Davidson, W.S. Helix orientation of the functional domains in apolipoprotein e in discoidal high density lipoprotein particles. J. Biol. Chem. 2004, 279, 14273-14279. [CrossRef]

20. Saito, H.; Dhanasekaran, P.; Baldwin, F.; Weisgraber, K.H.; Lund-Katz, S.; Phillips, M.C. Lipid binding-induced conformational change in human apolipoprotein E. Evidence for two lipid-bound states on spherical particles. J. Biol. Chem. 2001, 276, 40949-40954. [CrossRef]

21. Narayanaswami, V.; Ryan, R.O. Molecular basis of exchangeable apolipoprotein function. Biochim. Biophys. Acta 2000, 1483, 15-36. [CrossRef]

22. Frieden, C.; Wang, H.; Ho, C.M.W. A mechanism for lipid binding to apoE and the role of intrinsically disordered regions coupled to domain-domain interactions. Proc. Natl. Acad. Sci. USA 2017, 114, 6292-6297. [CrossRef] [PubMed]

23. Wilson, C.; Wardell, M.R.; Weisgraber, K.H.; Mahley, R.W.; Agard, D.A. Three-dimensional structure of the LDL receptor-binding domain of human apolipoprotein E. Science 1991, 252, 1817-1822. [CrossRef] [PubMed]

24. Wilson, C.; Mau, T.; Weisgraber, K.H.; Wardell, M.R.; Mahley, R.W.; Agard, D.A. Salt bridge relay triggers defective LDL receptor binding by a mutant apolipoprotein. Structure 1994, 2, 713-718. [CrossRef]

25. Polazzi, E.; Mengoni, I.; Pena-Altamira, E.; Massenzio, F.; Virgili, M.; Petralla, S.; Monti, B. Neuronal Regulation of Neuroprotective Microglial Apolipoprotein E Secretion in Rat In Vitro Models of Brain Pathophysiology. J. Neuropathol. Exp. Neurol. 2015, 74, 818-834. [CrossRef]

26. Xu, Q.; Bernardo, A.; Walker, D.; Kanegawa, T.; Mahley, R.W.; Huang, Y. Profile and regulation of apolipoprotein $\mathrm{E}$ (ApoE) expression in the CNS in mice with targeting of green fluorescent protein gene to the ApoE locus. J. Neurosci. 2006, 26, 4985-4994. [CrossRef]

27. Huang, Y.; Weisgraber, K.H.; Mucke, L.; Mahley, R.W. Apolipoprotein E: Diversity of cellular origins, structural and biophysical properties, and effects in Alzheimer's disease. J. Mol. Neurosci. 2004, 23, 189-204. [CrossRef]

28. Metzger, R.E.; LaDu, M.J.; Pan, J.B.; Getz, G.S.; Frail, D.E.; Falduto, M.T. Neurons of the human frontal cortex display apolipoprotein E immunoreactivity: Implications for Alzheimer's disease. J. Neuropathol. Exp. Neurol. 1996, 55, 372-380. [CrossRef]

29. Boyles, J.K.; Pitas, R.E.; Wilson, E.; Mahley, R.W.; Taylor, J.M. Apolipoprotein E associated with astrocytic glia of the central nervous system and with nonmyelinating glia of the peripheral nervous system. J. Clin. Investig. 1985, 76, 1501-1513. [CrossRef]

30. Achariyar, T.M.; Li, B.; Peng, W.; Verghese, P.B.; Shi, Y.; McConnell, E.; Benraiss, A.; Kasper, T.; Song, W.; Takano, T.; et al. Glymphatic distribution of CSF-derived apoE into brain is isoform specific and suppressed during sleep deprivation. Mol. Neurodegener. 2016, 11, 74. [CrossRef]

31. Flowers, S.A.; Grant, O.C.; Woods, R.J.; Rebeck, G.W. O-glycosylation on cerebrospinal fluid and plasma apolipoprotein E differs in the lipid-binding domain. Glycobiology 2019, 30, 74-85. [CrossRef] [PubMed]

32. Flowers, S.A.; Rebeck, G.W. APOE in the normal brain. Neurobiol. Dis. 2020, 136, 104724. [CrossRef] [PubMed]

33. Hu, Y.; Meuret, C.; Go, S.; Yassine, H.N.; Nedelkov, D. Simple and Fast Assay for Apolipoprotein E Phenotyping and Glycotyping: Discovering Isoform-Specific Glycosylation in Plasma and Cerebrospinal Fluid. J. Alzheimers Dis. 2020. [CrossRef] [PubMed]

34. Kockx, M.; Traini, M.; Kritharides, L. Cell-specific production, secretion, and function of apolipoprotein E. J. Mol. Med. 2018, 96, 361-371. [CrossRef] [PubMed]

35. Pitas, R.E.; Boyles, J.K.; Lee, S.H.; Foss, D.; Mahley, R.W. Astrocytes synthesize apolipoprotein E and metabolize apolipoprotein E-containing lipoproteins. Biochim. Biophys. Acta 1987, 917, 148-161. [CrossRef] 
36. Mailly, F.; Davignon, J.; Nestruck, A.C. Analytical isoelectric focusing with immobilized pH gradients of human apolipoprotein E from very low density lipoproteins and total plasma. J. Lipid Res. 1990, 31, 149-155.

37. DiBattista, A.M.; Dumanis, S.B.; Newman, J.; Rebeck, G.W. Identification and modification of amyloid-independent phenotypes of APOE4 mice. Exp. Neurol. 2016, 280, 97-105. [CrossRef]

38. Cruchaga, C.; Kauwe, J.S.; Nowotny, P.; Bales, K.; Pickering, E.H.; Mayo, K.; Bertelsen, S.; Hinrichs, A.; Alzheimer's Disease Neuroimaging Initiative; Fagan, A.M.; et al. Cerebrospinal fluid APOE levels: An endophenotype for genetic studies for Alzheimer's disease. Hum. Mol. Genet. 2012, 21, 4558-4571. [CrossRef]

39. Riddell, D.R.; Zhou, H.; Atchison, K.; Warwick, H.K.; Atkinson, P.J.; Jefferson, J.; Xu, L.; Aschmies, S.; Kirksey, Y.; Hu, Y.; et al. Impact of apolipoprotein E (ApoE) polymorphism on brain ApoE levels. J. Neurosci. 2008, 28, 11445-11453. [CrossRef]

40. Sullivan, P.M.; Han, B.; Liu, F.; Mace, B.E.; Ervin, J.F.; Wu, S.; Koger, D.; Paul, S.; Bales, K.R. Reduced levels of human apoE4 protein in an animal model of cognitive impairment. Neurobiol. Aging 2011, 32, 791-801. [CrossRef]

41. Martinez-Morillo, E.; Hansson, O.; Atagi, Y.; Bu, G.; Minthon, L.; Diamandis, E.P.; Nielsen, H.M. Total apolipoprotein $\mathrm{E}$ levels and specific isoform composition in cerebrospinal fluid and plasma from Alzheimer's disease patients and controls. Acta Neuropathol. 2014, 127, 633-643. [CrossRef] [PubMed]

42. Marchi, C.; Adorni, M.P.; Caffarra, P.; Ronda, N.; Spallazzi, M.; Barocco, F.; Galimberti, D.; Bernini, F.; Zimetti, F. ABCA1-and ABCG1-mediated cholesterol efflux capacity of cerebrospinal fluid is impaired in Alzheimer's disease. J. Lipid Res. 2019, 60, 1449-1456. [CrossRef] [PubMed]

43. Orth, M.; Bellosta, S. Cholesterol: Its regulation and role in central nervous system disorders. Cholest. 2012, 2012, 292598. [CrossRef] [PubMed]

44. Zhang, Y.; Sloan, S.A.; Clarke, L.E.; Caneda, C.; Plaza, C.A.; Blumenthal, P.D.; Vogel, H.; Steinberg, G.K.; Edwards, M.S.; Li, G.; et al. Purification and Characterization of Progenitor and Mature Human Astrocytes Reveals Transcriptional and Functional Differences with Mouse. Neuron 2016, 89, 37-53. [CrossRef] [PubMed]

45. Nieweg, K.; Schaller, H.; Pfrieger, F.W. Marked differences in cholesterol synthesis between neurons and glial cells from postnatal rats. J. Neurochem. 2009, 109, 125-134. [CrossRef]

46. Pfrieger, F.W.; Ungerer, N. Cholesterol metabolism in neurons and astrocytes. Prog. Lipid Res. 2011, 50, 357-371. [CrossRef]

47. Barber, C.N.; Raben, D.M. Lipid Metabolism Crosstalk in the Brain: Glia and Neurons. Front. Cell Neurosci. 2019, 13, 212. [CrossRef]

48. Moutinho, M.; Landreth, G.E. Therapeutic potential of nuclear receptor agonists in Alzheimer's disease. J. Lipid Res. 2017, 58, 1937-1949. [CrossRef]

49. Liang, Y.; Lin, S.; Beyer, T.P.; Zhang, Y.; Wu, X.; Bales, K.R.; DeMattos, R.B.; May, P.C.; Li, S.D.; Jiang, X.C.; et al. A liver $\mathrm{X}$ receptor and retinoid $\mathrm{X}$ receptor heterodimer mediates apolipoprotein $\mathrm{E}$ expression, secretion and cholesterol homeostasis in astrocytes. J. Neurochem. 2004, 88, 623-634. [CrossRef]

50. Horiuchi, Y.; Ohkawa, R.; Lai, S.J.; Yamazaki, A.; Ikoma, H.; Yano, K.; Kameda, T.; Tozuka, M. Characterization of the cholesterol efflux of apolipoprotein E-containing high-density lipoprotein in THP-1 cells. Biol. Chem. 2019, 400, 209-218. [CrossRef]

51. Tarr, P.T.; Edwards, P.A. ABCG1 and ABCG4 are coexpressed in neurons and astrocytes of the CNS and regulate cholesterol homeostasis through SREBP-2. J. Lipid Res. 2008, 49, 169-182. [CrossRef] [PubMed]

52. Burgess, B.L.; Parkinson, P.F.; Racke, M.M.; Hirsch-Reinshagen, V.; Fan, J.; Wong, C.; Stukas, S.; Theroux, L.; Chan, J.Y.; Donkin, J.; et al. ABCG1 influences the brain cholesterol biosynthetic pathway but does not affect amyloid precursor protein or apolipoprotein E metabolism in vivo. J. Lipid Res. 2008, 49, 1254-1267. [CrossRef] [PubMed]

53. Lund, E.G.; Guileyardo, J.M.; Russell, D.W. cDNA cloning of cholesterol 24-hydroxylase, a mediator of cholesterol homeostasis in the brain. Proc. Natl. Acad. Sci. USA 1999, 96, 7238-7243. [CrossRef] [PubMed]

54. Vance, J.E. Dysregulation of cholesterol balance in the brain: Contribution to neurodegenerative diseases. Dis. Model. Mech. 2012, 5, 746-755. [CrossRef]

55. Sengupta, M.B.; Mukhopadhyay, D. Possible role of apolipoprotein A1 in healing and cell death after neuronal injury. Front. Biosci. (Elite Ed.) 2016, 8, 460-477. 
56. Nathan, B.P.; Jiang, Y.; Wong, G.K.; Shen, F.; Brewer, G.J.; Struble, R.G. Apolipoprotein E4 inhibits, and apolipoprotein E3 promotes neurite outgrowth in cultured adult mouse cortical neurons through the low-density lipoprotein receptor-related protein. Brain Res. 2002, 928, 96-105. [CrossRef]

57. Pitas, R.E.; Ji, Z.S.; Weisgraber, K.H.; Mahley, R.W. Role of apolipoprotein E in modulating neurite outgrowth: Potential effect of intracellular apolipoprotein E. Biochem. Soc. Trans. 1998, 26, 257-262. [CrossRef]

58. Zhu, Y.; Bellosta, S.; Langer, C.; Bernini, F.; Pitas, R.E.; Mahley, R.W.; Assmann, G.; von Eckardstein, A. Low-dose expression of a human apolipoprotein $\mathrm{E}$ transgene in macrophages restores cholesterol efflux capacity of apolipoprotein E-deficient mouse plasma. Proc. Natl. Acad. Sci. USA 1998, 95, 7585-7590. [CrossRef]

59. Cantuti-Castelvetri, L.; Fitzner, D.; Bosch-Queralt, M.; Weil, M.T.; Su, M.; Sen, P.; Ruhwedel, T.; Mitkovski, M.; Trendelenburg, G.; Lutjohann, D.; et al. Defective cholesterol clearance limits remyelination in the aged central nervous system. Science 2018, 359, 684-688. [CrossRef]

60. Yamazaki, Y.; Zhao, N.; Caulfield, T.R.; Liu, C.C.; Bu, G. Apolipoprotein E and Alzheimer disease: Pathobiology and targeting strategies. Nat. Rev. Neurol. 2019, 15, 501-518. [CrossRef]

61. Shinohara, M.; Sato, N. The Roles of Apolipoprotein E, Lipids, and Glucose in the Pathogenesis of Alzheimer's Disease. Adv. Exp. Med. Biol. 2019, 1128, 85-101. [PubMed]

62. Roda, A.R.; Montoliu-Gaya, L.; Villegas, S. The Role of Apolipoprotein E Isoforms in Alzheimer's Disease. J. Alzheimers Dis. 2019, 68, 459-471. [CrossRef]

63. Ulrich, J.D.; Burchett, J.M.; Restivo, J.L.; Schuler, D.R.; Verghese, P.B.; Mahan, T.E.; Landreth, G.E.; Castellano, J.M.; Jiang, H.; Cirrito, J.R.; et al. In vivo measurement of apolipoprotein E from the brain interstitial fluid using microdialysis. Mol. Neurodegener. 2013, 8, 13. [CrossRef] [PubMed]

64. Valenza, M.; Rigamonti, D.; Goffredo, D.; Zuccato, C.; Fenu, S.; Jamot, L.; Strand, A.; Tarditi, A.; Woodman, B.; Racchi, M.; et al. Dysfunction of the cholesterol biosynthetic pathway in Huntington's disease. J. Neurosci. 2005, 25, 9932-9939. [CrossRef] [PubMed]

65. Minagawa, H.; Gong, J.S.; Jung, C.G.; Watanabe, A.; Lund-Katz, S.; Phillips, M.C.; Saito, H.; Michikawa, M. Mechanism underlying apolipoprotein E (ApoE) isoform-dependent lipid efflux from neural cells in culture. J. Neurosci. Res. 2009, 87, 2498-2508. [CrossRef] [PubMed]

66. Gong, J.S.; Morita, S.Y.; Kobayashi, M.; Handa, T.; Fujita, S.C.; Yanagisawa, K.; Michikawa, M. Novel action of apolipoprotein $\mathrm{E}$ (ApoE): ApoE isoform specifically inhibits lipid-particle-mediated cholesterol release from neurons. Mol. Neurodegener. 2007, 2, 9. [CrossRef]

67. Hara, M.; Matsushima, T.; Satoh, H.; Iso-o, N.; Noto, H.; Togo, M.; Kimura, S.; Hashimoto, Y.; Tsukamoto, K. Isoform-dependent cholesterol efflux from macrophages by apolipoprotein $\mathrm{E}$ is modulated by cell surface proteoglycans. Arter. Thromb. Vasc. Biol. 2003, 23, 269-274. [CrossRef]

68. Lin, Y.T.; Seo, J.; Gao, F.; Feldman, H.M.; Wen, H.L.; Penney, J.; Cam, H.P.; Gjoneska, E.; Raja, W.K.; Cheng, J.; et al. APOE4 Causes Widespread Molecular and Cellular Alterations Associated with Alzheimer's Disease Phenotypes in Human iPSC-Derived Brain Cell Types. Neuron 2018, 98, 1141-1154.e7. [CrossRef]

69. Julia, T.C.W.; Liang, S.A.; Qian, L.; Pipalia, N.H.; Chao, M.J.; Shi, Y.; Bertelsen, S.E.; Kapoor, M.; Marcora, E.; Sikora, E.; et al. Cholesterol and matrisome pathways dysregulated in human APOE $\varepsilon 4$ glia. BioRxiv 2019, 99, 713362.

70. Jeong, W.; Lee, H.; Cho, S.; Seo, J. ApoE4-Induced Cholesterol Dysregulation and Its Brain Cell Type-Specific Implications in the Pathogenesis of Alzheimer's Disease. Mol. Cells 2019, 42, 739-746.

71. de Chaves, E.P.; Narayanaswami, V. Apolipoprotein E and cholesterol in aging and disease in the brain. Future Lipidol. 2008, 3, 505-530. [CrossRef] [PubMed]

72. Papassotiropoulos, A.; Lutjohann, D.; Bagli, M.; Locatelli, S.; Jessen, F.; Buschfort, R.; Ptok, U.; Bjorkhem, I.; von Bergmann, K.; Heun, R. 24S-hydroxycholesterol in cerebrospinal fluid is elevated in early stages of dementia. J. Psychiatr. Res. 2002, 36, 27-32. [CrossRef]

73. Boehm-Cagan, A.; Bar, R.; Harats, D.; Shaish, A.; Levkovitz, H.; Bielicki, J.K.; Johansson, J.O.; Michaelson, D.M. Differential Effects of apoE4 and Activation of ABCA1 on Brain and Plasma Lipoproteins. PLoS ONE 2016, 11, e0166195. [CrossRef] [PubMed]

74. Grimm, M.O.W.; Michaelson, D.M.; Hartmann, T. Omega-3 fatty acids, lipids, and apoE lipidation in Alzheimer's disease: A rationale for multi-nutrient dementia prevention. J. Lipid Res. 2017, 58, 2083-2101. [CrossRef] 
75. Samieri, C.; Lorrain, S.; Buaud, B.; Vaysse, C.; Berr, C.; Peuchant, E.; Cunnane, S.C.; Barberger-Gateau, P. Relationship between diet and plasma long-chain n-3 PUFAs in older people: Impact of apolipoprotein E genotype. J. Lipid Res. 2013, 54, 2559-2567. [CrossRef]

76. Farmer, B.C.; Kluemper, J.; Johnson, L.A. Apolipoprotein E4 Alters Astrocyte Fatty Acid Metabolism and Lipid Droplet Formation. Cells 2019, 8, 182. [CrossRef]

77. McDougall, M.; Choi, J.; Magnusson, K.; Truong, L.; Tanguay, R.; Traber, M.G. Chronic vitamin E deficiency impairs cognitive function in adult zebrafish via dysregulation of brain lipids and energy metabolism. Free Radic. Biol. Med. 2017, 112, 308-317. [CrossRef]

78. Butterfield, D.A.; Johnson, L.A. APOE in Alzheimer's disease and neurodegeneration. Neurobiol. Dis. 2020, 139, 104847. [CrossRef]

79. Butterfield, D.A.; Mattson, M.P. Apolipoprotein E and oxidative stress in brain with relevance to Alzheimer's disease. Neurobiol. Dis. 2020, 138, 104795. [CrossRef]

80. Ramassamy, C.; Averill, D.; Beffert, U.; Theroux, L.; Lussier-Cacan, S.; Cohn, J.S.; Christen, Y.; Schoofs, A.; Davignon, J.; Poirier, J. Oxidative insults are associated with apolipoprotein E genotype in Alzheimer's disease brain. Neurobiol. Dis. 2000, 7, 23-37. [CrossRef]

81. Lauderback, C.M.; Kanski, J.; Hackett, J.M.; Maeda, N.; Kindy, M.S.; Butterfield, D.A. Apolipoprotein E modulates Alzheimer's Abeta(1-42)-induced oxidative damage to synaptosomes in an allele-specific manner. Brain Res. 2002, 924, 90-97. [CrossRef]

82. Pedersen, W.A.; Chan, S.L.; Mattson, M.P. A mechanism for the neuroprotective effect of apolipoprotein E: Isoform-specific modification by the lipid peroxidation product 4-hydroxynonenal. J. Neurochem. 2000, 74, 1426-1433. [CrossRef] [PubMed]

83. Kanekiyo, T.; Xu, H.; Bu, G. ApoE and Abeta in Alzheimer's disease: Accidental encounters or partners? Neuron 2014, 81, 740-754. [CrossRef] [PubMed]

84. Hu, J.; Liu, C.C.; Chen, X.F.; Zhang, Y.W.; Xu, H.; Bu, G. Opposing effects of viral mediated brain expression of apolipoprotein E2 (apoE2) and apoE4 on apoE lipidation and Abeta metabolism in apoE4-targeted replacement mice. Mol. Neurodegener. 2015, 10, 6. [CrossRef]

85. Hanson, A.J.; Bayer-Carter, J.L.; Green, P.S.; Montine, T.J.; Wilkinson, C.W.; Baker, L.D.; Watson, G.S.; Bonner, L.M.; Callaghan, M.; Leverenz, J.B.; et al. Effect of apolipoprotein E genotype and diet on apolipoprotein E lipidation and amyloid peptides: Randomized clinical trial. JAMA Neurol. 2013, 70, 972-980. [CrossRef]

86. Heinsinger, N.M.; Gachechiladze, M.A.; Rebeck, G.W. Apolipoprotein E Genotype Affects Size of ApoE Complexes in Cerebrospinal Fluid. J. Neuropathol. Exp. Neurol. 2016, 75, 918-924. [CrossRef] [PubMed]

87. Casey, C.S.; Atagi, Y.; Yamazaki, Y.; Shinohara, M.; Tachibana, M.; Fu, Y.; Bu, G.; Kanekiyo, T. Apolipoprotein E Inhibits Cerebrovascular Pericyte Mobility through a RhoA Protein-mediated Pathway. J. Biol. Chem. 2015, 290, 14208-14217. [CrossRef]

88. Koldamova, R.; Fitz, N.F.; Lefterov, I. ATP-binding cassette transporter A1: From metabolism to neurodegeneration. Neurobiol. Dis. 2014, 72, 13-21. [CrossRef]

89. Hubin, E.; Verghese, P.B.; van Nuland, N.; Broersen, K. Apolipoprotein E associated with reconstituted high-density lipoprotein-like particles is protected from aggregation. FEBS Lett. 2019, 593, 1144-1153. [CrossRef]

90. Chou, C.Y.; Lin, Y.L.; Huang, Y.C.; Sheu, S.Y.; Lin, T.H.; Tsay, H.J.; Chang, G.G.; Shiao, M.S. Structural variation in human apolipoprotein E3 and E4: Secondary structure, tertiary structure, and size distribution. Biophys. J. 2005, 88, 455-466. [CrossRef]

91. Perugini, M.A.; Schuck, P.; Howlett, G.J. Self-association of human apolipoprotein E3 and E4 in the presence and absence of phospholipid. J. Biol. Chem. 2000, 275, 36758-36765. [CrossRef] [PubMed]

92. Garai, K.; Frieden, C. The association-dissociation behavior of the ApoE proteins: Kinetic and equilibrium studies. Biochemistry 2010, 49, 9533-9541. [CrossRef] [PubMed]

93. Morikawa, M.; Fryer, J.D.; Sullivan, P.M.; Christopher, E.A.; Wahrle, S.E.; DeMattos, R.B.; O’Dell, M.A.; Fagan, A.M.; Lashuel, H.A.; Walz, T.; et al. Production and characterization of astrocyte-derived human apolipoprotein $\mathrm{E}$ isoforms from immortalized astrocytes and their interactions with amyloid-beta. Neurobiol. Dis. 2005, 19, 66-76. [CrossRef] [PubMed]

94. Fu, Y.; Zhao, J.; Atagi, Y.; Nielsen, H.M.; Liu, C.C.; Zheng, H.; Shinohara, M.; Kanekiyo, T.; Bu, G. Apolipoprotein E lipoprotein particles inhibit amyloid-beta uptake through cell surface heparan sulphate proteoglycan. Mol. Neurodegener. 2016, 11, 37. [CrossRef] [PubMed] 
95. Dodart, J.C.; Marr, R.A.; Koistinaho, M.; Gregersen, B.M.; Malkani, S.; Verma, I.M.; Paul, S.M. Gene delivery of human apolipoprotein E alters brain Abeta burden in a mouse model of Alzheimer's disease. Proc. Natl. Acad. Sci. USA 2005, 102, 1211-1216. [CrossRef]

96. Zhao, J.; Davis, M.D.; Martens, Y.A.; Shinohara, M.; Graff-Radford, N.R.; Younkin, S.G.; Wszolek, Z.K.; Kanekiyo, T.; Bu, G. APOE epsilon4/epsilon4 diminishes neurotrophic function of human iPSC-derived astrocytes. Hum. Mol. Genet. 2017, 26, 2690-2700. [CrossRef]

97. Peng, D.; Song, C.; Reardon, C.A.; Liao, S.; Getz, G.S. Lipoproteins produced by ApoE-/- astrocytes infected with adenovirus expressing human ApoE. J. Neurochem. 2003, 86, 1391-1402. [CrossRef]

98. Potier, M.-C.; Hanbouch, L.; Marquer, C. Cholesterol and ApoE in Alzheimer's disease. Oilseeds Fats Crop. Lipids 2018, 25, 6.

99. Marquer, C.; Laine, J.; Dauphinot, L.; Hanbouch, L.; Lemercier-Neuillet, C.; Pierrot, N.; Bossers, K.; Le, M.; Corlier, F.; Benstaali, C.; et al. Increasing membrane cholesterol of neurons in culture recapitulates Alzheimer's disease early phenotypes. Mol. Neurodegener. 2014, 9, 60. [CrossRef]

100. Burg, V.K.; Grimm, H.S.; Rothhaar, T.L.; Grosgen, S.; Hundsdorfer, B.; Haupenthal, V.J.; Zimmer, V.C.; Mett, J.; Weingartner, O.; Laufs, U.; et al. Plant sterols the better cholesterol in Alzheimer's disease? A mechanistical study. J. Neurosci. 2013, 33, 16072-16087. [CrossRef]

101. Morishima-Kawashima, M.; Han, X.; Tanimura, Y.; Hamanaka, H.; Kobayashi, M.; Sakurai, T.; Yokoyama, M.; Wada, K.; Nukina, N.; Fujita, S.C.; et al. Effects of human apolipoprotein E isoforms on the amyloid beta-protein concentration and lipid composition in brain low-density membrane domains. J. Neurochem. 2007, 101, 949-958. [CrossRef] [PubMed]

102. Fitz, N.F.; Cronican, A.A.; Lefterov, I.; Koldamova, R. Comment on "ApoE-directed therapeutics rapidly clear beta-amyloid and reverse deficits in AD mouse models". Science 2013, 340, 924-c. [CrossRef] [PubMed]

103. Cramer, P.E.; Cirrito, J.R.; Wesson, D.W.; Lee, C.Y.; Karlo, J.C.; Zinn, A.E.; Casali, B.T.; Restivo, J.L.; Goebel, W.D.; James, M.J.; et al. ApoE-directed therapeutics rapidly clear beta-amyloid and reverse deficits in AD mouse models. Science 2012, 335, 1503-1506. [CrossRef] [PubMed]

104. Kim, J.; Yoon, H.; Horie, T.; Burchett, J.M.; Restivo, J.L.; Rotllan, N.; Ramirez, C.M.; Verghese, P.B.; Ihara, M.; Hoe, H.S.; et al. microRNA-33 Regulates ApoE Lipidation and Amyloid-beta Metabolism in the Brain. J. Neurosci. 2015, 35, 14717-14726. [CrossRef]

105. Rawat, V.; Wang, S.; Sima, J.; Bar, R.; Liraz, O.; Gundimeda, U.; Parekh, T.; Chan, J.; Johansson, J.O.; Tang, C.; et al. ApoE4 Alters ABCA1 Membrane Trafficking in Astrocytes. J. Neurosci. 2019, 39, 9611-9622. [CrossRef]

106. Hafiane, A.; Johansson, J.O.; Genest, J. ABCA1 Agonist Mimetic Peptide CS-6253 Induces Microparticles Release From Different Cell Types by ABCA1-Efflux-Dependent Mechanism. Can. J. Cardiol. 2019, 35, 770-781. [CrossRef]

107. Boehm-Cagan, A.; Bar, R.; Liraz, O.; Bielicki, J.K.; Johansson, J.O.; Michaelson, D.M. ABCA1 Agonist Reverses the ApoE4-Driven Cognitive and Brain Pathologies. J. Alzheimers Dis. 2016, 54, 1219-1233. [CrossRef]

108. Handattu, S.P.; Monroe, C.E.; Nayyar, G.; Palgunachari, M.N.; Kadish, I.; van Groen, T.; Anantharamaiah, G.M.; Garber, D.W. In vivo and in vitro effects of an apolipoprotein e mimetic peptide on amyloid-beta pathology. J. Alzheimers Dis. 2013, 36, 335-347. [CrossRef]

109. Chernick, D.; Ortiz-Valle, S.; Jeong, A.; Swaminathan, S.K.; Kandimalla, K.K.; Rebeck, G.W.; Li, L. High-density lipoprotein mimetic peptide 4F mitigates amyloid-beta-induced inhibition of apolipoprotein E secretion and lipidation in primary astrocytes and microglia. J. Neurochem. 2018, 147, 647-662. [CrossRef]

110. Dunbar, R.L.; Movva, R.; Bloedon, L.T.; Duffy, D.; Norris, R.B.; Navab, M.; Fogelman, A.M.; Rader, D.J. Oral Apolipoprotein A-I Mimetic D-4F Lowers HDL-Inflammatory Index in High-Risk Patients: A First-in-Human Multiple-Dose, Randomized Controlled Trial. Clin. Transl. Sci. 2017, 10, 455-469. [CrossRef]

111. Bloedon, L.T.; Dunbar, R.; Duffy, D.; Pinell-Salles, P.; Norris, R.; DeGroot, B.J.; Movva, R.; Navab, M.; Fogelman, A.M.; Rader, D.J. Safety, pharmacokinetics, and pharmacodynamics of oral apoA-I mimetic peptide D-4F in high-risk cardiovascular patients. J. Lipid Res. 2008, 49, 1344-1352. [CrossRef] [PubMed]

112. Jiang, Q.; Lee, C.Y.; Mandrekar, S.; Wilkinson, B.; Cramer, P.; Zelcer, N.; Mann, K.; Lamb, B.; Willson, T.M.; Collins, J.L.; et al. ApoE promotes the proteolytic degradation of Abeta. Neuron 2008, 58, 681-693. [CrossRef] [PubMed] 
113. Riddell, D.R.; Zhou, H.; Comery, T.A.; Kouranova, E.; Lo, C.F.; Warwick, H.K.; Ring, R.H.; Kirksey, Y.; Aschmies, S.; Xu, J.; et al. The LXR agonist TO901317 selectively lowers hippocampal Abeta42 and improves memory in the Tg2576 mouse model of Alzheimer's disease. Mol. Cell Neurosci. 2007, 34, 621-628. [CrossRef] [PubMed]

114. Koldamova, R.P.; Lefterov, I.M.; Staufenbiel, M.; Wolfe, D.; Huang, S.; Glorioso, J.C.; Walter, M.; Roth, M.G.; Lazo, J.S. The liver $X$ receptor ligand T0901317 decreases amyloid beta production in vitro and in a mouse model of Alzheimer's disease. J. Biol. Chem. 2005, 280, 4079-4088. [CrossRef] [PubMed]

115. Corona, A.W.; Kodoma, N.; Casali, B.T.; Landreth, G.E. ABCA1 is Necessary for Bexarotene-Mediated Clearance of Soluble Amyloid Beta from the Hippocampus of APP/PS1 Mice. J. Neuroimmune Pharmacol. 2016, 11, 61-72. [CrossRef]

116. Boehm-Cagan, A.; Michaelson, D.M. Reversal of apoE4-driven brain pathology and behavioral deficits by bexarotene. J. Neurosci. 2014, 34, 7293-7301. [CrossRef]

117. Tai, L.M.; Koster, K.P.; Luo, J.; Lee, S.H.; Wang, Y.T.; Collins, N.C.; Ben Aissa, M.; Thatcher, G.R.; $\mathrm{LaDu}, \mathrm{M} . J$. Amyloid-beta pathology and APOE genotype modulate retinoid $\mathrm{X}$ receptor agonist activity in vivo. J. Biol. Chem. 2014, 289, 30538-30555. [CrossRef]

118. Mariani, M.M.; Malm, T.; Lamb, R.; Jay, T.R.; Neilson, L.; Casali, B.; Medarametla, L.; Landreth, G.E. Neuronally-directed effects of RXR activation in a mouse model of Alzheimer's disease. Sci. Rep. 2017, 7, 42270. [CrossRef]

119. Mounier, A.; Georgiev, D.; Nam, K.N.; Fitz, N.F.; Castranio, E.L.; Wolfe, C.M.; Cronican, A.A.; Schug, J.; Lefterov, I.; Koldamova, R. Bexarotene-Activated Retinoid X Receptors Regulate Neuronal Differentiation and Dendritic Complexity. J. Neurosci. 2015, 35, 11862-11876. [CrossRef]

120. Wang, W.; Nakashima, K.I.; Hirai, T.; Inoue, M. Neuroprotective effect of naturally occurring RXR agonists isolated from Sophora tonkinensis Gagnep. on amyloid-beta-induced cytotoxicity in PC12 cells. J. Nat. Med. 2019, 73, 154-162. [CrossRef]

121. Wang, W.; Nakashima, K.I.; Hirai, T.; Inoue, M. Anti-inflammatory effects of naturally occurring retinoid $\mathrm{X}$ receptor agonists isolated from Sophora tonkinensis Gagnep. via retinoid X receptor/liver X receptor heterodimers. J. Nat. Med. 2019, 73, 419-430. [CrossRef] [PubMed]

122. Wang, C.; Najm, R.; Xu, Q.; Jeong, D.E.; Walker, D.; Balestra, M.E.; Yoon, S.Y.; Yuan, H.; Li, G.; Miller, Z.A.; et al. Gain of toxic apolipoprotein E4 effects in human iPSC-derived neurons is ameliorated by a small-molecule structure corrector. Nat. Med. 2018, 24, 647-657. [CrossRef]

123. Chen, H.K.; Ji, Z.S.; Dodson, S.E.; Miranda, R.D.; Rosenblum, C.I.; Reynolds, I.J.; Freedman, S.B.; Weisgraber, K.H.; Huang, Y.; Mahley, R.W. Apolipoprotein E4 domain interaction mediates detrimental effects on mitochondria and is a potential therapeutic target for Alzheimer disease. J. Biol. Chem. 2011, 286, 5215-5221. [CrossRef]

124. Chen, H.K.; Liu, Z.; Meyer-Franke, A.; Brodbeck, J.; Miranda, R.D.; McGuire, J.G.; Pleiss, M.A.; Ji, Z.S.; Balestra, M.E.; Walker, D.W.; et al. Small molecule structure correctors abolish detrimental effects of apolipoprotein E4 in cultured neurons. J. Biol. Chem. 2012, 287, 5253-5266. [CrossRef] [PubMed]

125. Brodbeck, J.; McGuire, J.; Liu, Z.; Meyer-Franke, A.; Balestra, M.E.; Jeong, D.E.; Pleiss, M.; McComas, C.; Hess, F.; Witter, D.; et al. Structure-dependent impairment of intracellular apolipoprotein E4 trafficking and its detrimental effects are rescued by small-molecule structure correctors. J. Biol. Chem. 2011, 286, 17217-17226. [CrossRef] [PubMed]

126. Raulin, A.C.; Kraft, L.; Al-Hilaly, Y.K.; Xue, W.F.; McGeehan, J.E.; Atack, J.R.; Serpell, L. The Molecular Basis for Apolipoprotein E4 as the Major Risk Factor for Late-Onset Alzheimer's Disease. J. Mol. Biol 2019, 431, 2248-2265. [CrossRef] [PubMed]

127. Liao, F.; Li, A.; Xiong, M.; Bien-Ly, N.; Jiang, H.; Zhang, Y.; Finn, M.B.; Hoyle, R.; Keyser, J.; Lefton, K.B.; et al. Targeting of nonlipidated, aggregated apoE with antibodies inhibits amyloid accumulation. J. Clin. Investig. 2018, 128, 2144-2155. [CrossRef]

128. Rosenberg, J.B.; Kaplitt, M.G.; De, B.P.; Chen, A.; Flagiello, T.; Salami, C.; Pey, E.; Zhao, L.; Ricart Arbona, R.J.; Monette, S.; et al. AAVrh.10-Mediated APOE2 Central Nervous System Gene Therapy for APOE4-Associated Alzheimer's Disease. Hum. Gene. Ther. Clin. Dev. 2018, 29, 24-47. [CrossRef]

129. Hudry, E.; Dashkoff, J.; Roe, A.D.; Takeda, S.; Koffie, R.M.; Hashimoto, T.; Scheel, M.; Spires-Jones, T.; Arbel-Ornath, M.; Betensky, R.; et al. Gene transfer of human Apoe isoforms results in differential modulation of amyloid deposition and neurotoxicity in mouse brain. Sci Transl. Med. 2013, 5, 212ra161. [CrossRef] 
130. Zhao, L.; Gottesdiener, A.J.; Parmar, M.; Li, M.; Kaminsky, S.M.; Chiuchiolo, M.J.; Sondhi, D.; Sullivan, P.M.; Holtzman, D.M.; Crystal, R.G.; et al. Intracerebral adeno-associated virus gene delivery of apolipoprotein E2 markedly reduces brain amyloid pathology in Alzheimer's disease mouse models. Neurobiol. Aging 2016, 44, 159-172. [CrossRef]

131. DeMattos, R.B.; Brendza, R.P.; Heuser, J.E.; Kierson, M.; Cirrito, J.R.; Fryer, J.; Sullivan, P.M.; Fagan, A.M.; Han, X.; Holtzman, D.M. Purification and characterization of astrocyte-secreted apolipoprotein E and J-containing lipoproteins from wild-type and human apoE transgenic mice. Neurochem. Int. 2001, 39, 415-425. [CrossRef]

132. Wahrle, S.E.; Jiang, H.; Parsadanian, M.; Legleiter, J.; Han, X.; Fryer, J.D.; Kowalewski, T.; Holtzman, D.M. ABCA1 is required for normal central nervous system ApoE levels and for lipidation of astrocyte-secreted apoE. J. Biol. Chem. 2004, 279, 40987-40993. [CrossRef]

133. Wahrle, S.E.; Jiang, H.; Parsadanian, M.; Kim, J.; Li, A.; Knoten, A.; Jain, S.; Hirsch-Reinshagen, V.; Wellington, C.L.; Bales, K.R.; et al. Overexpression of ABCA1 reduces amyloid deposition in the PDAPP mouse model of Alzheimer disease. J. Clin. Investig. 2008, 118, 671-682. [CrossRef] [PubMed]

134. Hirsch-Reinshagen, V.; Zhou, S.; Burgess, B.L.; Bernier, L.; McIsaac, S.A.; Chan, J.Y.; Tansley, G.H.; Cohn, J.S.; Hayden, M.R.; Wellington, C.L. Deficiency of ABCA1 impairs apolipoprotein E metabolism in brain. J. Biol. Chem. 2004, 279, 41197-41207. [CrossRef] [PubMed]

135. Wahrle, S.E.; Jiang, H.; Parsadanian, M.; Hartman, R.E.; Bales, K.R.; Paul, S.M.; Holtzman, D.M. Deletion of Abca1 increases Abeta deposition in the PDAPP transgenic mouse model of Alzheimer disease. J. Biol. Chem. 2005, 280, 43236-43242. [CrossRef]

136. Koldamova, R.; Staufenbiel, M.; Lefterov, I. Lack of ABCA1 considerably decreases brain ApoE level and increases amyloid deposition in APP23 mice. J. Biol. Chem. 2005, 280, 43224-43235. [CrossRef]

137. Koldamova, R.; Lefterov, I. Role of LXR and ABCA1 in the pathogenesis of Alzheimer's disease-implications for a new therapeutic approach. Curr. Alzheimer Res. 2007, 4, 171-178. [CrossRef]

138. Nordestgaard, L.T.; Tybjaerg-Hansen, A.; Nordestgaard, B.G.; Frikke-Schmidt, R. Loss-of-function mutation in ABCA1 and risk of Alzheimer's disease and cerebrovascular disease. Alzheimers Dement. 2015, 11, 1430-1438. [CrossRef]

139. Yassine, H.N.; Feng, Q.; Chiang, J.; Petrosspour, L.M.; Fonteh, A.N.; Chui, H.C.; Harrington, M.G. ABCA1-Mediated Cholesterol Efflux Capacity to Cerebrospinal Fluid Is Reduced in Patients With Mild Cognitive Impairment and Alzheimer's Disease. J. Am. Heart Assoc. 2016, 5, e002886. [CrossRef]

140. Tai, L.M.; Thomas, R.; Marottoli, F.M.; Koster, K.P.; Kanekiyo, T.; Morris, A.W.; Bu, G. The role of APOE in cerebrovascular dysfunction. Acta Neuropathol. 2016, 131, 709-723. [CrossRef]

141. Namjoshi, D.R.; Martin, G.; Donkin, J.; Wilkinson, A.; Stukas, S.; Fan, J.; Carr, M.; Tabarestani, S.; Wuerth, K.; Hancock, R.E.; et al. The liver X receptor agonist GW3965 improves recovery from mild repetitive traumatic brain injury in mice partly through apolipoprotein E. PLoS ONE 2013, 8, e53529. [CrossRef] [PubMed]

142. Cummings, J.L.; Zhong, K.; Kinney, J.W.; Heaney, C.; Moll-Tudla, J.; Joshi, A.; Pontecorvo, M.; Devous, M.; Tang, A.; Bena, J. Double-blind, placebo-controlled, proof-of-concept trial of bexarotene Xin moderate Alzheimer's disease. Alzheimers Res. Ther. 2016, 8, 4. [CrossRef] [PubMed]

143. Schultz, J.R.; Tu, H.; Luk, A.; Repa, J.J.; Medina, J.C.; Li, L.; Schwendner, S.; Wang, S.; Thoolen, M.; Mangelsdorf, D.J.; et al. Role of LXRs in control of lipogenesis. Genes Dev. 2000, 14, 2831-2838. [CrossRef]

144. Jalil, A.; Bourgeois, T.; Menegaut, L.; Lagrost, L.; Thomas, C.; Masson, D. Revisiting the Role of LXRs in PUFA Metabolism and Phospholipid Homeostasis. Int. J. Mol. Sci. 2019, 20, 3787. [CrossRef] [PubMed]

145. Brecht, W.J.; Harris, F.M.; Chang, S.; Tesseur, I.; Yu, G.Q.; Xu, Q.; Dee Fish, J.; Wyss-Coray, T.; Buttini, M.; Mucke, L.; et al. Neuron-specific apolipoprotein e4 proteolysis is associated with increased tau phosphorylation in brains of transgenic mice. J. Neurosci. 2004, 24, 2527-2534. [CrossRef]

146. Mahley, R.W.; Huang, Y. Small-molecule structure correctors target abnormal protein structure and function: Structure corrector rescue of apolipoprotein E4-associated neuropathology. J. Med. Chem. 2012, 55, 8997-9008. [CrossRef]

147. Koch, S.; Donarski, N.; Goetze, K.; Kreckel, M.; Stuerenburg, H.J.; Buhmann, C.; Beisiegel, U. Characterization of four lipoprotein classes in human cerebrospinal fluid. J. Lipid Res. 2001, 42, 1143-1151.

(C) 2020 by the authors. Licensee MDPI, Basel, Switzerland. This article is an open access article distributed under the terms and conditions of the Creative Commons Attribution (CC BY) license (http://creativecommons.org/licenses/by/4.0/). 